\title{
Decay Rate of Escherichia coli in a Mountainous Tropical Headwater Wetland
}

\author{
Paty Nakhle ${ }^{1}$, Laurie Boithias 1,*(D), Anne Pando-Bahuon ${ }^{2}$, Chanthamousone Thammahacksa ${ }^{2}$, \\ Nicolas Gallion ${ }^{1}$ (D), Phabvilay Sounyafong ${ }^{2}$, Norbert Silvera ${ }^{2}$, Keooudone Latsachack ${ }^{2}$, Bounsamay Soulileuth ${ }^{2}$, \\ Emma J. Rochelle-Newall ${ }^{3} \mathbb{D}$, Yoan Marcangeli ${ }^{3} \mathbb{D}$, Alain Pierret ${ }^{2}$ and Olivier Ribolzi $^{1}$
}

1 Géosciences Environnement Toulouse (GET), Université de Toulouse, CNRS, IRD, UPS, 31400 Toulouse, France; paty.nakhle@get.omp.eu (P.N.); gallion.nicolas@gmail.com (N.G.); olivier.ribolzi@get.omp.eu (O.R.)

2 c/o Department of Agricultural Land Management (DALaM), Institut de Recherche Pour le Développement (IRD), IEES-Paris UMR 242, Sorbonne Université, Vientiane 01000, Laos; anne.pando@ird.fr (A.P.-B.); louyird@gmail.com (C.T.); phabvilay_laopdr@yahoo.com (P.S.); norbert.silvera@ird.fr (N.S.); wannaki@gmail.com (K.L.); sbounsamay@gmail.com (B.S.); alain.pierret@ird.fr (A.P.)

3 Institute of Ecology and Environmental Sciences of Paris (iEES-Paris), Sorbonne Université, University Paris Est Creteil, IRD, CNRS, INRA, 75005 Paris, France; emma.rochelle-newall@ird.fr (E.J.R.-N.); yoan.marcangeli@sorbonne-universite.fr (Y.M.)

* Correspondence: laurie.boithias@get.omp.eu

check for updates

Citation: Nakhle, P.; Boithias, L.; Pando-Bahuon, A.; Thammahacksa, C.; Gallion, N.; Sounyafong, P.; Silvera, N.; Latsachack, K.; Soulileuth B.; Rochelle-Newall, E.J.; et al. Decay Rate of Escherichia coli in a Mountainous Tropical Headwater Wetland. Water 2021, 13, 2068. https://doi.org/10.3390/w13152068

Academic Editor: Stefano Amalfitano

Received: 18 May 2021

Accepted: 24 July 2021

Published: 29 July 2021

Publisher's Note: MDPI stays neutral with regard to jurisdictional claims in published maps and institutional affiliations.

Copyright: (C) 2021 by the authors. Licensee MDPI, Basel, Switzerland. This article is an open access article distributed under the terms and conditions of the Creative Commons Attribution (CC BY) license (https:/ / creativecommons.org/licenses/by/ $4.0 /)$.

\begin{abstract}
Surface water contamination by pathogen bacteria remains a threat to public health in the rural areas of developing countries. Fecal indicator bacteria (FIB) like Escherichia coli (E. coli) are widely used to assess water contamination, but their behavior in tropical ecosystems is poorly documented. Our study focused on headwater wetlands which are likely to play a key role in stream water purification of fecal pollutants. Our main objectives were to: (i) evaluate decay rates (k) of the total, particle-attached and free-living E. coli; (ii) quantify the relative importance of solar radiation exposition and suspended particles deposition on k; and (iii) investigate E. coli survival in the deposited sediment. We installed and monitored 12 mesocosms, $4500 \mathrm{~mL}$ each, across the main headwater wetland of the Houay Pano catchment, northern Lao People's Democratic Republic (Lao PDR), for 8 days. The four treatments with triplicates were: sediment deposition-light (DL); sediment deposition-dark (DD); sediment resuspension-light (RL); and sediment resuspension-dark (RD). Particle-attached bacteria predominated in all mesocosms $\left(97 \pm 6 \%\right.$ ). Decay rates ranged from $1.43 \pm 0.15$ to $1.17 \pm 0.13$ day $^{-1}$ for DL and DD treatments, and from $0.50 \pm 0.15$ to $-0.14 \pm 0.37$ day $^{-1}$ for RL and RD treatments. Deposition processes accounted for an average of $92 \%$ of $E$. coli stock reduction, while solar radiation accounted for around $2 \%$ over the experiment duration. The sampling of $E$. coli by temporary resuspension of the deposited sediment showed $\mathrm{k}$ values close to zero, suggesting potential survival or even growth of bacteria in the sediment. The present findings may help parameterizing hydrological and water quality models in a tropical context.
\end{abstract}

Keywords: fecal indicator bacteria; Lao PDR; Mekong basin; water purification; survival rates; mesocosms; solar radiation; sedimentation; particle deposition; particle resuspension

\section{Introduction}

One in four people globally drink water contaminated with fecal matter [1]. Surface water contamination by fecal pathogenic microorganisms is indeed a threat for public health worldwide [2]. Diarrheal diseases including gastroenteritis, mostly caused by water-borne pathogens, were responsible for the deaths of 1.6 million people in 2017 [3]. This major public health issue especially affects developing countries in the intertropical band, where populations rely directly on local resources and have poor access to clean water, sanitation, and hygiene [4]. For instance, rural communities in the Mekong basin 
depend directly on small tributaries and natural canal systems to fulfil their domestic water needs [5]. In Lao People's Democratic Republic (Lao PDR), temporary camps, gardens, and fishponds can be found in the riparian zones where contamination levels were found to be high [6,7]. Moreover, riparian zones in tropical systems are often characterized by wetlands and swampy areas [6].

Ecosystems such as wetlands have multiple ecological functions, like reducing flow velocity and filtering pollutants and fecal pathogens from surface water, resulting in the reduction of suspended particles and pollutant loading to downstream environments, and thereby improving water quality $[8,9]$. Wetlands, widespread in the humid tropics, are common landscape features in the Mekong basin [10,11], and provide multiple ecosystem services including food production [12,13], flood control [14], habitat biodiversity [15], and water purification [16]. If large wetlands of fluvial plains are quite well studied [17,18], the functioning of those located along or nearby mountainous headwater streams are little studied, hence still poorly understood. Headwater wetlands, although representing a limited proportion of the drainage area of catchments, are likely to strongly affect the hydrological behavior [19] and biogeochemical characteristics of mountain streams [20,21]. In a study based on a large data set consisting of 35 developing countries, it has been shown that upstream watershed conditions including wetlands can significantly influence downstream water quality [22]. To be able to effectively reduce the risk on human health [23], it is imperative to improve our understanding of environmental factors controlling fecal pathogens in tropical aquatic systems like headwater wetlands.

There is a growing scientific community interested in the main mechanisms involved in pathogens reduction within wetlands, mainly documented in temperate regions $[9,24,25]$. The fecal contamination of water bodies is typically assessed by measuring levels of fecal indicator bacteria (FIB), e.g., Escherichia coli (E. coli) [26,27]. To our knowledge, little information exists on the survival of FIB in tropical headwater wetlands, which are generally characterized by high and stable temperatures, dense riparian vegetation, high ecological diversity, and long water residence time [28]. All these characteristics can influence the E. coli decay rates. Several studies pointed out the potential of $E$. coli to survive and possibly even proliferate in secondary and tertiary habitats such as soils and streambed sediments under tropical conditions [29-33]. Given the potential persistence of E. coli in the environment and its frequent use as a FIB, a further understanding of its decay mechanisms is needed to evaluate the environmental microbial contamination to which the rural population may be exposed.

Several studies have identified solar radiation as one of the most important factors controlling and reducing E. coli concentration in surface water bodies [34-36]. It has been demonstrated that bacteria are susceptible to ultraviolet wavelengths within the solar spectrum wavelengths causing direct DNA damage [36-38]. When exposed to solar radiation, FIB can get inactivated by entering a state in which they maintain some metabolic activity but lose their culturability [38]. The "viable non-culturable state" is a state of dormancy of bacteria characterized by a very low metabolic activity [39]. In relatively shallow aquatic ecosystems like wetlands, solar radiation can have a direct impact on bacterial decay rates within water column $[40,41]$. However, dense vegetation cover may dampen the net impact of radiations. Furthermore, bacterial attachment to suspended particles can also play a key role in protecting bacteria from the photo-inactivation [42]. Bacteria attached to suspended particles at the top of the water column can access nutrients [43] and be subject to settle in the bottom of a wetland. This deposition process is thought to be one of the major mechanisms of bacterial removal [44] and is therefore widely used to decontaminate water in constructed wetlands [45]. However, some studies in freshwater ecosystems [46,47] and marine ecosystems [29] showed the ability of E. coli to survive longer in sediments than in the water column. Thus, the bottom sediments of wetlands could potentially serve as a reservoir of FIB, which could be released into the water column during erosive stormflow events $[6,48]$. Various other environmental factors were also shown to impact $E$. coli decay 
rate in water, such as temperature [49,50], nutrients availability [51], dissolved organic carbon availability [52], salinity [53], and predation [54].

In this study, our first hypothesis is that if most $E$. coli in the water column are present in the attached form, the settling down of suspended particles should be a major process for reducing the bacterial load in the stream water. Our second hypothesis is that in humid tropical conditions, the effect of light should be strongly attenuated by the dense vegetation cover typical of humid environments. Hence, considering a mountainous headwater wetland located within the Houay Pano catchment (northern Lao PDR), whose land use is representative of humid tropical agroecosystems of South-East Asia [55], the objectives of this study were: (i) to evaluate decay rates of the total, particle-attached, and free-living E. coli, (ii) to quantify the relative importance of solar radiation exposition and suspended particles deposition on decay rates, and (iii) to investigate the survival of E. coli in the deposited bottom sediment.

The majority of FIB decay experiments were conducted under laboratory-controlled conditions [41,42,56,57], which take into account a selected range of physical, chemical, and biological factors found in natural environments. In this study, in order to obtain decay rates estimates as realistic as possible, we adopted an experimental approach based on measurements and using in situ mesocosms. The latter were filled with contaminated water collected from the Houay Pano stream and were installed in the water column of the wetland, hence exposed to natural diurnal cycle variations.

\section{Materials and Methods}

\subsection{Study Area}

The experiment was carried out in the Houay Pano catchment $\left(19^{\circ} 51^{\prime} \mathrm{N}-102^{\circ} 10^{\prime} \mathrm{E}\right)$, located $10 \mathrm{~km}$ south of Luang Prabang, northern Lao PDR (Figure 1a). The 60-ha Houay Pano catchment is a sub-catchment of the Houay Xon, a tributary of the Mekong River. Slopes in the catchment range from $0 \%$ to $171 \%$ with an average of $54 \%$ [6]. This experimental site is part of the Multiscale TROPIcal CatchmentS (M-TROPICS) critical zone observatory [55] which operates under the umbrella of the Observatoires de la Zone Critique: Applications et Recherche (OZCAR) [58]. This catchment is representative of the mountainous agroecosystems of South-East Asia. The climate is tropical wet and dry climate, abbreviated "Aw climate" in the Köppen-Geiger-Pohl system, and characterized by a monsoon regime, with two contrasted seasons: a dry season from November to May and a rainy season from June to October. The mean annual temperature is $23.4^{\circ} \mathrm{C}$. The mean annual rainfall is $1366 \mathrm{~mm}(\mathrm{CV}=0.23)$, about $71 \%(\mathrm{CV}=0.09)$ of which, falls during the rainy season [55]. The headwater wetland (0.19 ha) is located in the central part of the Houay Pano catchment (Figure 1b). The wetland drains 32.5 ha and is permanently fed by groundwater [59]. It is a typical upland headwater wetland, colonized by $2-4 \mathrm{~m}$ high Napier grass (Pennisetum purpureum Schumach.), and surrounded with teak tree plantations, fallow land, and secondary forest [59].

In spite of the relatively small suspended particles size (median is between 6 and $24 \mu \mathrm{m}$ ) measured in the upstream inflow [60], this wetland is known to have a high sediment trapping efficiency [61], due to hydro-morphological conditions that favor particles settling [62]: low water line slope gradient (3.5\%), limited hydraulic radius of the wetted area $\left(0.02-0.2 \mathrm{~m}\right.$ ), low to very low apparent stream flow velocity (close to $0.001 \mathrm{~m} \mathrm{~s}^{-1}$ ), and high vegetation cover (Napier grass).

It should be noted that, if Napier grass cover is high year round, it is sometimes cut to be used as fodder, or occasionally replaced by vegetable plants such as watercress [63]. At the end of the dry season, the Napier grass cover is also sometimes accidentally or deliberately burnt by farmers. As a result, the global solar radiation reaching the water surface is likely to vary according to agricultural practices and land use. During this study, the canopy density of Napier grass (i.e., the percentage of the vertical projection area of vegetation on the ground) along the wetland was between 45 and $100 \%$. 


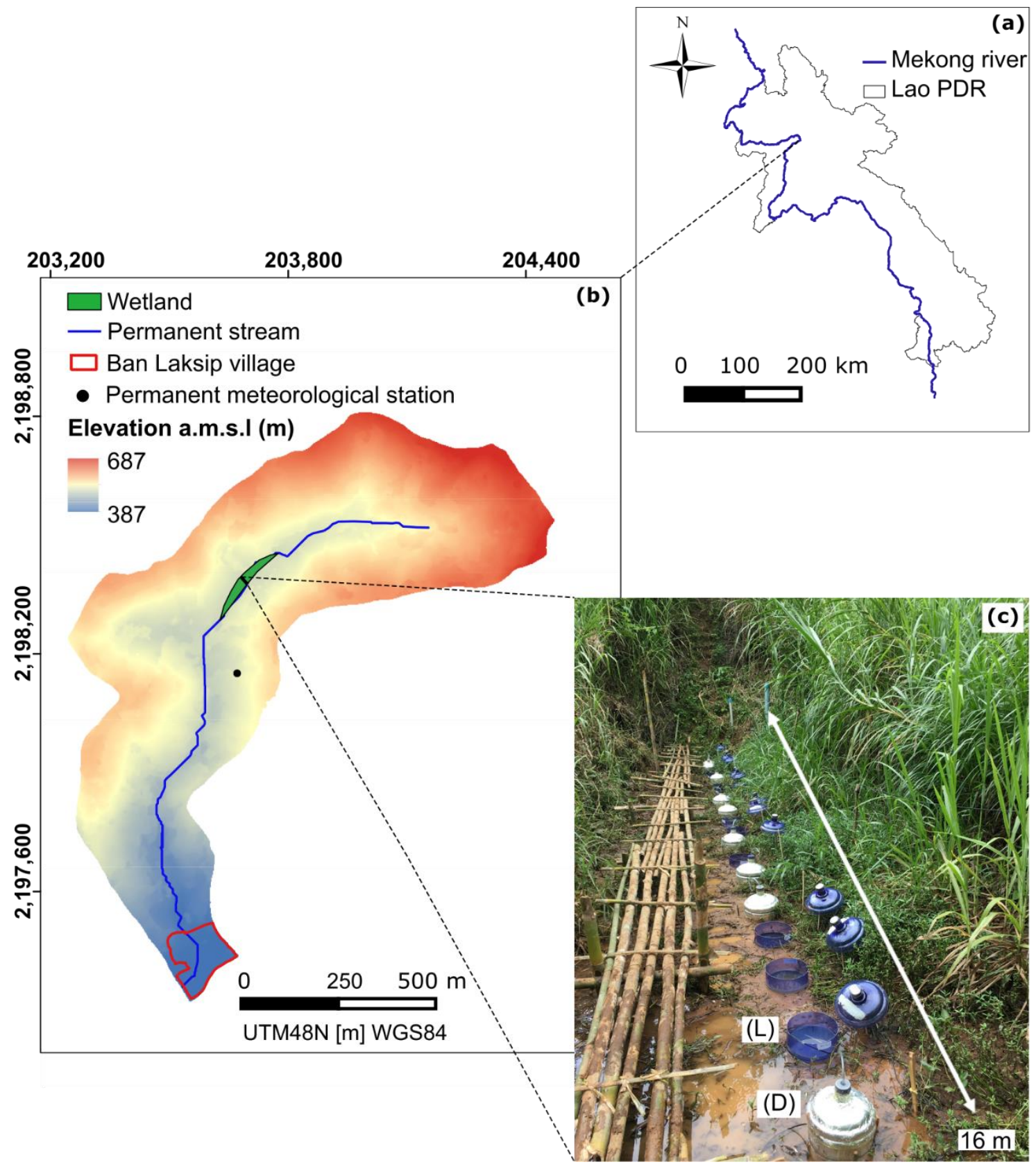

Figure 1. Geographical location of (a) the Houay Pano catchment in northern Lao PDR, and (b) location of the study site in the headwater wetland; (c) photo of the transect within the wetland where the mesocosms exposed to natural light (L), the mesocosms kept in the dark (D), and the bamboo bridge, were installed 9-16 August 2019.

\subsection{Experimental Design}

Fifteen mesocosms (51 cm high and $27 \mathrm{~cm}$ in diameter transparent plastic buckets) were installed across the main headwater wetland of the Houay Pano catchment for a monitoring period of 8 days (Figure $1 \mathrm{c}$ ).

Mesocosms were divided into 4 treatments ( 3 replicates per treatment):

- Two of these treatments, i.e., suspended particles deposition in the light (DL) and suspended particles deposition in the dark (DD), were designed to quantify the decay rate of E. coli under wetland-like hydrodynamic conditions enabling the fall of suspended particles (i.e., absence or very low turbulence in the water column), with and without daylight (DL and DD respectively), to simulate the strong attenuation of the transmitted luminous flux to the water surface by dense vegetation cover (Figure 2). 
- Two other treatments, i.e., sediment resuspension in the light (RL) and sediment resuspension in the dark (RD), were aimed to evaluate the possible survival or even growth of E. coli in the deposited sediment. To this end, bacteria that had been deposited at the bottom of the mesocosm with the solid particles were resuspended by a daily 1-min manual stirring of the water column using sterile gloves, preceding each sampling. Here the cases with and without daylight (RL and RD respectively) were also tested.

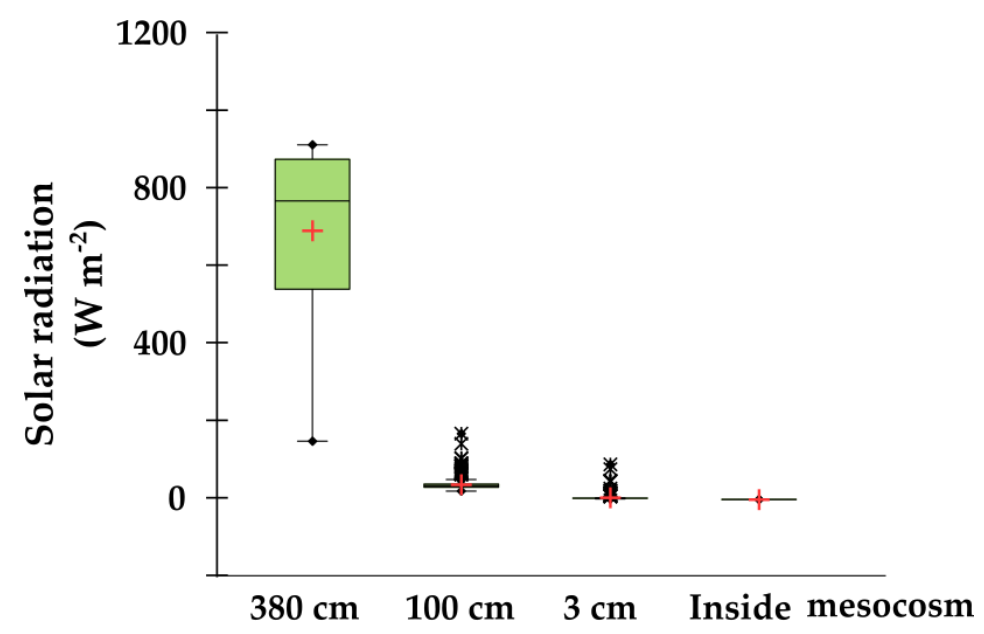

\section{Heights}

Figure 2. Boxplots of solar intensity $\left(\mathrm{W} \mathrm{m}^{-2}\right)$ measured between 11 am and $3 \mathrm{pm}$ for two days (24 and 25 October 2020) within the headwater wetland in Houay Pano catchment, northern Lao PDR, characterized with high Napier grass (Pennisetum purpureum Schumach.) cover (i.e., 100\% at the measurement site) at 4 different heights: $380 \mathrm{~cm}, 100 \mathrm{~cm}, 3 \mathrm{~cm}$, and inside of a covered top mesocosm. The red crosses indicate the means. The central horizontal bars are the medians. The lower and upper limits of the box are the 25th and 75th percentiles, respectively. The lower and upper lines of the boxes are the 10th and 90th percentiles. Points above or below the upper and lower limits are considered as outliers.

We used an additional set of three mesocosms (control) to verify the absence of external contamination during the experiment (raindrops splash, dry atmospheric deposits, etc.).

Open top mesocosms (covered in case of rainfall event to avoid external contamination and concentration dilution) were used for the treatments with natural sunlight cycle exposure (DL, RL, and control). Covered top mesocosms using two layers of plastic covers wrapped in aluminum foil with ventilation holes to ensure the aeration inside the mesocosm were used for the treatments in the dark (DD and RD).

Mesocosms were randomly distributed by series of replicates, along a transect perpendicular to the stream flowing within the headwater wetland (Figure 1c). The mesocosms were installed in the center of the wetland, spaced one meter apart, held straight with bamboo rods, and driven $10 \mathrm{~cm}$ deep into the streambed sediment (Figure 1c).

A field worker was permanently present on the study site throughout the experiment duration, in order to ensure that no external source would contaminate the mesocosms (e.g., wild animals), and to avoid any change in mesocosm water balance by closing all the mesocosms during rainfall events. Before the start of the experiment, a bamboo bridge was built to facilitate the setup of the experiment and to access the mesocosms without contaminating them (Figure 1c).

\subsection{Mesocosms Preparation}

We used stream water to ensure the presence of nutrients, particles, and predators found in natural aquatic environment. We collected Houay Pano stream water in the Ban 
Laksip village (Figure 1) approximately $10 \mathrm{~cm}$ below the water surface, $6 \mathrm{~h}$ before the installation of mesocosms. Approximately $70 \mathrm{~L}$ of water were collected into 4 sterilized $20 \mathrm{~L}$ buckets. The water from the 4 buckets was then mixed in a single large barrel in the vicinity of the experiment site, and vigorously stirred to ensure a homogenized distribution of the bacteria and of the suspended particles concentration in water before being distributed using a sterile $1000 \mathrm{~mL}$ test tube in the 12 mesocosms used for the four treatments. Each mesocosm was filled with $4500 \mathrm{~mL}$ of water.

For the three control mesocosms, we used groundwater collected within the Houay Pano catchment. We pumped groundwater from 6 piezometers located inside and on the edge of the wetland and characterized by low E. coli concentration (436 $\left.\pm 102 \mathrm{MPN} 100 \mathrm{~mL}^{-1}\right)$ when compared to water collected from Houay Pano stream $\left(435,506 \pm 215,275 \mathrm{MPN} 100 \mathrm{~mL}^{-1}\right)$. The biogeochemical background of the groundwater was comparable to that of the water collected in Houay Pano stream. The water was homogenized in a second barrel and $4500 \mathrm{~mL}$ were distributed in each of to three control mesocosms.

\subsection{Analytical Methods: Concentrations of E. coli, TSS, DOC, and Turbidity}

We collected $30 \mathrm{~mL}$ water samples from each mesocosm, daily over 8 days (D0, D1, D2, D3, D4, D5, and D7), $1 \mathrm{~cm}$ beneath the water surface using 50-mL sterile plastic syringes. We stored the samples at ambient temperature and in the dark until measurement. We analyzed these samples within $6 \mathrm{~h}$, by taking a subsample of $10 \mathrm{~mL}$ to determine the turbidity using a turbidity meter (EUTECH Instruments TN-100). We took another subsample of $10 \mathrm{~mL}$ to determine total E. coli concentration [E. coli $]_{\text {total }}$ (=particle-attached + free-living E. coli), and free-living E. coli concentration $[E \text {. coli }]_{\text {free. We calculated particle- }}$ attached E. coli concentration ([E. coli $\left.]_{\text {att }}\right)$ from the difference between $[E \text {. coli }]_{\text {total }}$ and $[\text { E. coli }]_{\text {free }}$ To determine $[E \text {. coli }]_{\text {total }}$ and $[E \text {. coli }]_{\text {free, }}$ we used $5 \mathrm{~mL}$ of raw water for total E. coli counts, and we filtered $5 \mathrm{~mL}$ of raw water through cellulose esters filters (Millipore, $0.3 \mu \mathrm{m}, 47 \mathrm{~mm}$ ) to separate the free-living E. coli in the collected filtrate from the particleattached E. coli remaining on the filter [64]. The method used for measuring [E. coli] $]_{\text {total }}$ and [E. coli $]_{\text {free }}$ is the standardized microplate method (ISO 9308-3). This technique is based on a 48 -h incubation at $44{ }^{\circ} \mathrm{C}$ of each sample, at four dilution rates $(1: 2,1: 20,1: 200,1: 2000$ for treatments; and 1, 1:2, 1:20, 1:200 for control), in a culture medium specific for E. coli on a 96-well microplate (MUG/EC, Biokar Diagnostics). We determined [E. coli $]_{\text {total }}$ and [E. coli $]_{\text {free }}$ expressed in terms of most probable number per $100 \mathrm{~mL}\left(\mathrm{MPN} 100 \mathrm{~mL}^{-1}\right)$, by counting the number of positive wells for each microplate, and by applying a statistical analysis based on Poisson's law [65].

We collected $80 \mathrm{~mL}$ water samples every other day (D0, D2, D4, and D7), $1 \mathrm{~cm}$ beneath the water surface using 50-mL sterile plastic syringes, and we stored them at ambient temperature and in the dark until measurement within $6 \mathrm{~h}$ after sampling. We filtered the water sample through a pre-weighted cellulose acetate filter (Whatman, $0.2 \mu \mathrm{m}, 47 \mathrm{~mm}$ ). To measure the total suspended sediment concentration ([TSS]), we used $20 \mathrm{~mL}$ of the collected filtrate. Then, we dried the retained matter on the filter at $105^{\circ}$ during $24 \mathrm{~h}$, and we calculated [TSS] by dividing the difference in weights of the filter before and after filtration, by the filtered volume (APHA, 1998). To determine the concentration of dissolved organic carbon ([DOC]) in water samples, we used a duplicate of a $30 \mathrm{~mL}$ of the collected filtrate. $30-\mathrm{mL}$ [DOC] samples were stored in pre-combusted $\left(450{ }^{\circ} \mathrm{C}\right.$, overnight $)$ glass tubes, sealed with a Teflon lined cap, after preservation with $36 \mu \mathrm{L} \mathrm{85 \%}$ phosphoric acid $\left(\mathrm{H}_{3} \mathrm{PO}_{4}\right)$. [DOC] was then measured with a Shimadzu TOC-V CSH analyzer, using potassium phthalate calibration standards over the measurement range $\left(0-450 \mu \mathrm{mol} \mathrm{C} \mathrm{L}{ }^{-1}\right)$.

\subsection{Environmental Variables: Rainfall, Temperatures and Global Solar Radiation}

A permanent meteorological station, Campbell BWS200 with ARG100-0.2 mm capacity tipping-bucket (Campbell Scientific, Logan, Utah, USA), set up downstream of the swamp recorded rainfall at 1-min intervals. A meteorological station installed in the wetland recorded sediment temperature $\left({ }^{\circ} \mathrm{C}\right)$ at 6-min intervals, using Campbell T108s probes 
inserted $7.5 \mathrm{~cm}$ deep in the wetland sediment (T1). The air temperature $\left({ }^{\circ} \mathrm{C}\right)$ was also recorded at 6-min intervals using a Campbell CS215 probe. The water column temperature $\left({ }^{\circ} \mathrm{C}\right)$ in the wetland was recorded at 6-min intervals with an AquiStar CT2X probe.

The global solar radiation $\left(\mathrm{W} \mathrm{m}^{-2}\right)$ averaged at 6 min intervals was recorded using a pyranometer Campbell CS300.

In order to evaluate the solar intensity attenuation by the Napier grass cover (i.e., $100 \%$ at the center of the wetland where the experiment was conducted) and to check the dark conditions inside the mesocosms, we measured the solar radiation intensities at 3 different heights above the wetland bottom sediments $(380 \mathrm{~cm}, 100 \mathrm{~cm}$ and $3 \mathrm{~cm})$ and inside the mesocosm (Figure $\mathrm{S} 1$ ). The global solar radiation $\left(\mathrm{W} \mathrm{m}^{-2}\right)$ averaged at 6 -min intervals were recorded during two days using 4 pyranometers: SP110 (Campbell CS300) at $380 \mathrm{~cm}$ height; RG100 Solems at $100 \mathrm{~cm}$ height; Li200X (LI-COR PY34392) at $3 \mathrm{~cm}$ height; and RG100 Solems inside the mesocosm.

\subsection{Apparent Decay Rates, $T_{50}$ and $T_{90}$ Values}

In this study, what we refer to as 'apparent' decay rate (k) accounts for the net equilibrium between the increase and the decrease in E. coli concentration due to possible bacteria growth, bacteria mortality, and suspended particles attachment and settlement, i.e., deposition process. The apparent decay rates of $E$. coli for each of the four treatments were estimated by fitting an exponential equation to the bacterial concentration measured over time. The equation has been expressed as a first order kinetic decay proposed by [66]:

$$
\begin{aligned}
\mathrm{C}_{t} & =\mathrm{C}_{i} \cdot \mathrm{e}^{-k t} \\
\ln \mathrm{C}_{t} & =\ln \mathrm{C}_{i}-k t
\end{aligned}
$$

where $C_{t}$ is the measured concentration of E. coli at time $\mathrm{t}$ in MPN $100 \mathrm{~mL}^{-1}, C_{i}$ is the measured initial concentration of $E$. coli in MPN $100 \mathrm{~mL}^{-1}, k$ is the decay rate in day ${ }^{-1}$, and $t$ is the elapsed time in days. The $k$ value was determined for both the free-living and particleattached fractions of $E$. coli concentration and for the total $E$. coli concentration. Average $k$ and standard errors were calculated for the triplicates of each treatment. When outliers due to external contaminations were detected, values of $k$ were obtained after excluding the outliers in order to reduce the variance due to external contamination following the possible submersion of a mesocosm.

The time (hours) required for initial bacterial concentration to decrease by $50 \%$ and $90 \%$ is $T_{50}$ (E. coli population half-life) and $T_{90}$, respectively. The previous equation can be written as:

$$
\begin{aligned}
& T_{50}=\frac{-\ln (0.5)}{k * 24} \\
& T_{90}=\frac{-\ln (0.1)}{k * 24}
\end{aligned}
$$

\subsection{E. coli Stock Variations}

In order to estimate the respective contributions of solar radiation and particle deposition to bacterial apparent decay during the experiment, we applied a simple balance method. In this approach, only solar radiation-related decay and suspended particles deposition were assumed to be involved. Therefore, E. coli stocks at the start of the experiment $\left(\mathrm{S}_{\mathrm{o}}\right)$ and after a period of time $\Delta \mathrm{t}\left(\mathrm{S}_{\mathrm{t}}\right)$ in the water column were compared between the DL and DD treatments. $S_{0}$ was obtained by multiplying a normalized initial concentration $\left(C_{o}=500,000 \mathrm{MPN} 100 \mathrm{~mL}^{-1}\right)$ by the initial volume of water $\left(V_{o}=4500 \mathrm{~mL}\right) . \mathrm{S}_{\mathrm{t}}$ was calculated by multiplying the final volume of water $\left(\mathrm{V}_{t}\right)$ by the final E. coli concentration $\left(\mathrm{C}_{\mathrm{f}}\right)$ in DL and DD treatments. $C_{f}$ was obtained using Equation (1) considering the fitted value of the apparent decay rates (Table 1). The number of decayed E. coli in the water column was deduced from the difference between $S_{o}$ and $S_{t}$ at each sampling date $\Delta t$. The total number of decayed $E$. coli in the water column $\left(\mathrm{N}_{\mathrm{t}}\right)$ was calculated considering that DL treatment cumulates the decay effects of both solar radiation and particle deposition. The number of 
decayed E. coli due to deposition $\left(n_{t}^{D}\right)$ only was obtained from the DD treatment. Finally, the number of decayed E. coli due to solar radiation $\left(n_{t}^{L}\right)$ was deduced from the difference between $\mathrm{N}_{\mathrm{t}}$ and $n_{t}^{D}$. A Monte Carlo approach was then used to quantify the uncertainties in $n_{t}^{D}$ and $n_{t}^{L}$ calculations (e.g., [67]). The details of the equations that describe the E. coli stock variations, and their associated uncertainties, are given in the Supplementary Materials.

Table 1. Average apparent decay rates $\mathrm{k}\left(\right.$ day $\left.^{-1}\right) \pm$ standard error $\left(\right.$ day $\left.^{-1}\right)$ of replicates per treatment for total E. coli and for the free-living and particle-attached fractions of $E$. coli measured in mesocosms installed in the headwater wetland of the Houay Pano catchment, northern Lao PDR, from 9 August to 16 August 2019: Resuspension—Light (RL); Deposition—Light (DL); Resuspension-Dark (RD); Deposition-Dark (DD).

\begin{tabular}{ccccc}
\hline Treatments & RL & DL & RD & DD \\
\hline Total & $0.50 \pm 0.15$ & $1.43 \pm 0.15$ & $-0.14 \pm 0.37$ & $1.17 \pm 0.13$ \\
Attached & $0.49 \pm 0.15$ & $1.41 \pm 0.15$ & $-0.15 \pm 0.38$ & $1.18 \pm 0.13$ \\
Free & $1.20 \pm 0.13$ & $1.53 \pm 0.19$ & $0.28 \pm 0.35$ & $1.36 \pm 0.32$ \\
\hline
\end{tabular}

\section{Results}

The results are presented by first describing the environmental context in the headwater wetland of the Houay Pano catchment during the experiment duration, followed by our main findings as we monitor the temporal variations of physico-chemical and microbiological variables in the mesocosms [68]. Based on the observations, we calculated the $E$. coli decay rates, $\mathrm{T}_{50}$ and $\mathrm{T}_{90}$ values, as well as $E$. coli stock variations.

\subsection{Environmental Variables}

We measured the solar radiation intensities at 3 different heights above the wetland bottom sediments and inside the mesocosms to evaluate the solar intensity attenuation by the Napier grass cover and to check the dark conditions inside the mesocosms (Figure S1). Solar radiation measured at $380 \mathrm{~cm}$ height, which is above the vegetation height (Figure S1), ranged between 40 and $1068 \mathrm{~W} \mathrm{~m}^{-2}$ while at $100 \mathrm{~cm}$, which is inside the vegetation, it ranged between 3 and $170 \mathrm{~W} \mathrm{~m}^{-2}$ (Figure 2). At $3 \mathrm{~cm}$ height (under the vegetation), the solar radiation varied between 0 and $91 \mathrm{~W} \mathrm{~m}^{-2}$ (Figure 2). Solar radiations were highly attenuated inside the wetland vegetation, which blocks an important part of the radiation from reaching the water column and bottom sediment. Inside the mesocosm, the solar radiation were almost completely blocked and dark conditions prevailed (Figure 2).

We monitored, during the experiment duration, three main environmental variables including rainfall, global solar radiation, and the temperature of the air, swamp water, and swamp sediment (Figure 3). Three rainfall events over the experiment duration were observed on 9, 10, and 12 August 2019, with a daily cumulative rainfall of 12.2, 12.6, and $8.4 \mathrm{~mm}$, respectively (Figure $3 \mathrm{a}$ ). The temperatures measured during the experiment followed diurnal cycles. Air temperature varied between 24 and $36^{\circ} \mathrm{C}$. Likewise, diurnal temperature variations were also observed in wetland sediment with highest temperatures up to $29^{\circ} \mathrm{C}$ recorded during the daytime. Wetland water temperature remained stable around $25{ }^{\circ} \mathrm{C}$ (Figure 3b). The global solar radiation followed diurnal cycles with peaks recorded in the middle of the day with a maximum value of $1160 \mathrm{~W} \mathrm{~m}^{-2}$ (Figure 3c).

\subsection{Physico-Chemical and Microbiological Variables}

[TSS] and turbidity decreased over time (Figure 4a-d). Two different trends are noted. In both light and dark conditions, RD and RL showed stable [TSS] the first 4 days of an average around $0.39 \pm 0.20 \mathrm{~g} \mathrm{~L}^{-1}$ and $0.43 \pm 0.23 \mathrm{~g} \mathrm{~L}^{-1}$, respectively, and a slight decrease during the rest of the experiment to reach $0.27 \pm 0.04 \mathrm{~g} \mathrm{~L}^{-1}$ and $0.22 \pm 0.07 \mathrm{~g} \mathrm{~L}^{-1}$, respectively. The mesocosms left to deposition processes in DD and DL showed a rapid decrease of [TSS] from the first day of experiment until the end of the experiment, reaching values around $0.02 \mathrm{~g} \mathrm{~L}^{-1}$. [DOC] increased between the first and the third day of the experiment 
in the four treatments (Figure 4e,f). [DOC] increased the most in light conditions, with values ranging from 0.08 to $0.12 \mathrm{mg} \mathrm{L}^{-1}$ in $\mathrm{RL}$ and 0.08 to $0.19 \mathrm{mg} \mathrm{L}^{-1}$ in DL and decreased during the rest of the experiment.

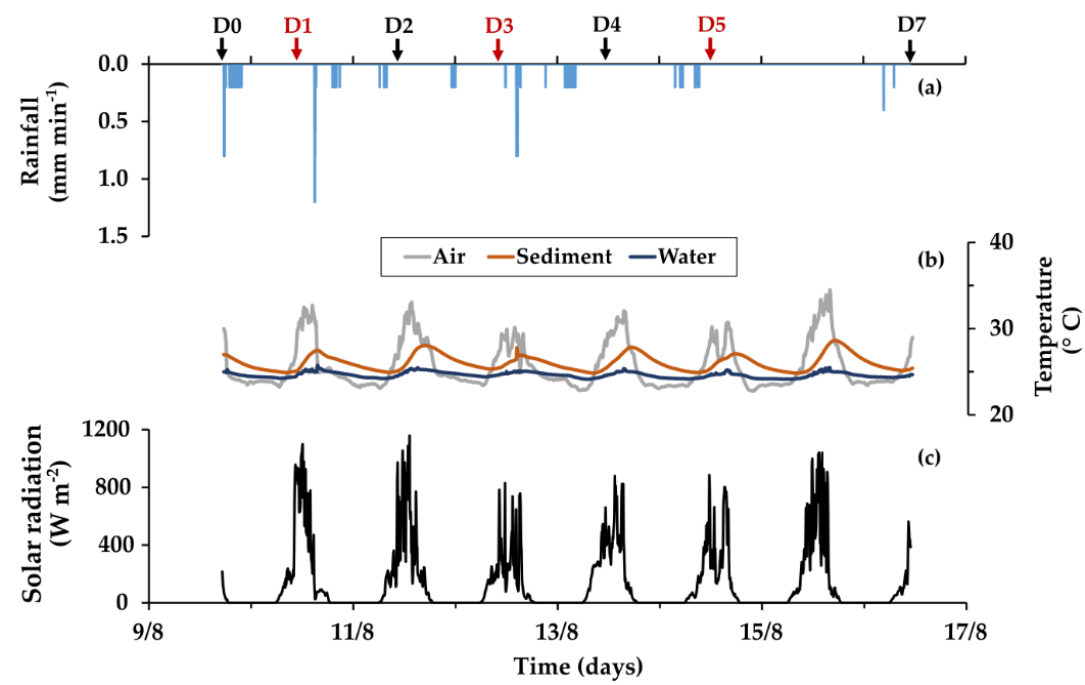

Figure 3. Temporal variations of environmental variables in the headwater wetland of the Houay Pano catchment, northern Lao PDR, 9-16 August 2019: (a) Rainfall ( $\mathrm{mm} \mathrm{min}^{-1}$ ); (b) Temperatures $\left({ }^{\circ} \mathrm{C}\right)$ recorded in the swamp sediment, in the swamp water, and in the air; $(\mathbf{c})$ solar radiation $\left(\mathrm{W} \mathrm{m}^{-2}\right)$. The vertical black arrows above the upper y axis represent the days of sampling to measure turbidity and [E. coli] and the red arrows represent the days of sampling to measure [DOC] and [TSS] in addition to turbidity and [E. coli].

On the first day, [E. coli $]_{\text {free }}$ in the four treatments ranged from 9700 to $51,600 \mathrm{MPN}$ $100 \mathrm{~mL}^{-1}$ (Figure $4 \mathrm{~g}, \mathrm{~h}$ ). [E. coli $]_{\text {free }}$ decreased over the course of the experiment to reach $0 \mathrm{MPN} 100 \mathrm{~mL}^{-1}$ on the fourth day in DD and DL, and on the last day in RL. However, the decrease of [E. coli $]_{\text {free }}$ in RD was slower over time and reached $66 \pm 88 \mathrm{MPN} 100 \mathrm{~mL}^{-1}$ on day 6 but increased again to $2470 \pm 975 \mathrm{MPN} 100 \mathrm{~mL}^{-1}$ on the last day of the experiment.

On the first day, [E. coli] $]_{\text {total }}$ in the four treatments ranged from 330,000 to 505,000 MPN $100 \mathrm{~mL}^{-1}$ (Figure $4 \mathrm{i}, \mathrm{j}$ ). The changes over time varied from one treatment to another. We can dissociate two distinct trends. The first group corresponds to DD and DL, showing an important $[E \text {. coli }]_{\text {total }}$ decrease during the experiment. The $[E \text {. coli }]_{\text {total }}$ at the end of the experiment was $226 \pm 25 \mathrm{MPN} 100 \mathrm{~mL}^{-1}$ for DD and $50 \pm 58 \mathrm{MPN} 100 \mathrm{~mL}^{-1}$ for DL. Within these two treatments, we also dissociated the faster [E. coli $]_{\text {total }}$ decrease in the mesocosm exposed to solar radiation (DL) as compared to the mesocosm left in the dark (DD). The second group corresponds to RD and RL, showing a more stable dynamic when compared with DD and DL. Within these two treatments, the mesocosm exposed to light (RL) showed a stable [E. coli $]_{\text {total }}$ and a slight decrease at the last day of the experiment, while the mesocosm in dark (RD) showed a slight $[E \text {. coli }]_{\text {total }}$ increase. At the end of the experiment, [E. coli $]_{\text {total }}$ was $38,763 \pm 44,890 \mathrm{MPN} 100 \mathrm{~mL}^{-1}$ for RD and $24,221 \pm 33,238 \mathrm{MPN} 100 \mathrm{~mL}^{-1}$ for RL.

\subsection{Apparent Decay Rates and $T_{50}$ and $T_{90}$ Values}

The apparent decay rates of total $E$. coli concentration for mesocosms left to deposit $\left(\mathrm{k}=1.43 \mathrm{day}^{-1}\right.$ in DL and $1.17 \mathrm{day}^{-1}$ in DD) were higher than in mesocosms subject to resuspension $\left(\mathrm{k}=0.50 \mathrm{day}^{-1}\right.$ in $\mathrm{RL}$ and $-0.14 \mathrm{day}^{-1}$ in $\left.\mathrm{RD}\right)$. Likewise, the apparent decay rates for mesocosms exposed to solar radiation (RL and DL) were higher than mesocosms left in the dark (RD and DD). However, in contrast to the majority of treatments, it is important to note the specific behavior of E. coli concentration tending to be stable and slightly increasing in RD mesocosms (Table 1). 



Figure 4. Temporal variations of physico-chemical and microbiological variables in the mesocosm installed in the headwater wetland of the Houay Pano catchment, northern Lao PDR, from 9 August to 16 August 2019. Left side panels are for Resuspension-Dark (RD) and Deposition-Dark (DD), whereas right panels are for Resuspension-Light (RL) and Deposition-Light (DL). (a,b) Turbidity: turbidity (NTU); (c,d) [TSS]: total suspended sediment concentration $\left(\mathrm{g} \mathrm{L}^{-1}\right) ;(\mathbf{e}, \mathbf{f})$ [DOC]: dissolved organic carbon concentration $\left(\mathrm{mg} \mathrm{L}^{-1}\right) ;(\mathbf{g}, \mathbf{h})[\text { E. coli }]_{\text {free }}$ : free-living E. coli concentration (MPN $\left.100 \mathrm{~mL}^{-1}\right) ;(\mathbf{i}, \mathbf{j})[\text { E. coli }]_{\text {total }}$ : total E. coli concentration (MPN $\left.100 \mathrm{~mL}^{-1}\right)$.

Similarly, the particle-attached fraction of E. coli showed the same dynamics in terms of apparent decay rates in all four treatments. However, more accentuated apparent decay rates of free-living E. coli were noted in DL $\left(\mathrm{k}=1.53\right.$ day $\left.^{-1}\right)$, DD $\left(\mathrm{k}=1.36 \mathrm{day}^{-1}\right)$, RL $\left(\mathrm{k}=1.20 \mathrm{day}^{-1}\right)$, and $\mathrm{RD}\left(\mathrm{k}=0.28 \mathrm{day}^{-1}\right)$ in a decreasing order. Contrarily to the particleattached fraction, dynamics of free-living E. coli in RD mesocosms tended to decrease over the incubation period $\left(\mathrm{k}=0.28 \mathrm{day}^{-1}\right)$ (Table 1$)$.

The time required to achieve $T_{50}$, i.e. $50 \%$ reduction of [E. coli $]_{\text {total }}$, was the longest in RD followed by RL ranging respectively between 117.8 and 33.4 hours, and the shortest for DL followed by DD ranging respectively between 11.6 and 14.2 hours. The particleattached fraction of E. coli showed similar $T_{50}$ values in all four treatments. The $T_{50}$ in $R D$ and RL is divided by two for [E. coli $]_{\text {free, }}$, ranging respectively between 59.4 and 13.9 hours. As for the DL and DD, the $\mathrm{T}_{50}$ is similar to the $[E \text {. coli }]_{\text {total }}$, ranging respectively between 10.9 and 12.2 hours (Table 2). 
Table 2. $\mathrm{T}_{50}(\mathrm{~h})$ and $\mathrm{T}_{90}(\mathrm{~h})$ values for total E. coli and for the free-living and particle-attached fractions of E. coli measured in mesocosms installed in the headwater wetland of the Houay Pano catchment, northern Lao PDR, from August 9 to August 16, 2019: Resuspension-Light (RL); Deposition—Light (DL); Resuspension—Dark (RD); Deposition—Dark (DD).

\begin{tabular}{ccccccccc}
\hline Treatments & \multicolumn{2}{c}{ RL } & \multicolumn{2}{c}{ DL } & \multicolumn{2}{c}{ RD } & \multicolumn{2}{c}{ DD } \\
\hline & $\mathbf{T}_{\mathbf{5 0}}$ & $\mathbf{T}_{\mathbf{9 0}}$ & $\mathbf{T}_{\mathbf{5 0}}$ & $\mathbf{T}_{\mathbf{9 0}}$ & $\mathbf{T}_{\mathbf{5 0}}$ & $\mathbf{T}_{\mathbf{9 0}}$ & $\mathbf{T}_{\mathbf{5 0}}$ & $\mathbf{T}_{\mathbf{9 0}}$ \\
\hline Total & 33.4 & 111 & 11.6 & 38.6 & 117.8 & 391.2 & 14.2 & 47.2 \\
Attached & 33.9 & 112.8 & 11.8 & 39.2 & 110.9 & 368.4 & 14.1 & 46.8 \\
Free & 13.9 & 46 & 10.9 & 36.1 & 59.4 & 197.4 & 12.2 & 40.6 \\
\hline
\end{tabular}

The same dynamics were noted for the time required to achieve $\mathrm{T}_{90}$, i.e. $90 \%$ reduction of [E. coli $]_{\text {total }}$, which was the longest in RD followed by RL, varying respectively between 391.2 and 111 hours, and the shortest for DL followed by DD, varying respectively between 38.6 and 47.2 hours. The particle-attached fraction of E. coli showed similar $\mathrm{T}_{90}$ values in all four treatments. The $\mathrm{T}_{90}$ in RL and RD is divided by two for [E. coli $]_{\text {free, }}$, varying respectively between 197.4 and 46 hours. As for the DL and DD, the $T_{90}$ is similar to the [E. coli $]_{\text {total, }}$ varying respectively between 40.6 and 36.1 hours (Table 2).

\subsection{E. coli Stock Variations}

The E. coli stock variations approach allowed us to estimate the respective contribution of each factor separately, deposition and solar radiation, to bacterial apparent decay over the duration of the experiment (Figure 5). The deposition accounted for the decrease in initial E. coli number by an average of $64 \%$ at day 1 of the experiment, by $89 \%$ at day 2 , and by more than $96 \%$ from day 3 till the end of the experiment. Solar radiation accounted for the decrease in initial E. coli number of around $7 \%$ at day $1,4 \%$ at day 2 , and the contribution continuously decreased till the end of the experiment (Figure 5). The deposition process accounted for an average of $92 \%$ of the decayed E. coli number over the experiment duration, while solar radiation accounted for around $2 \%$. The remaining $6 \%$ is the residual fraction of decayed E. coli in the experiment (Figure S2).

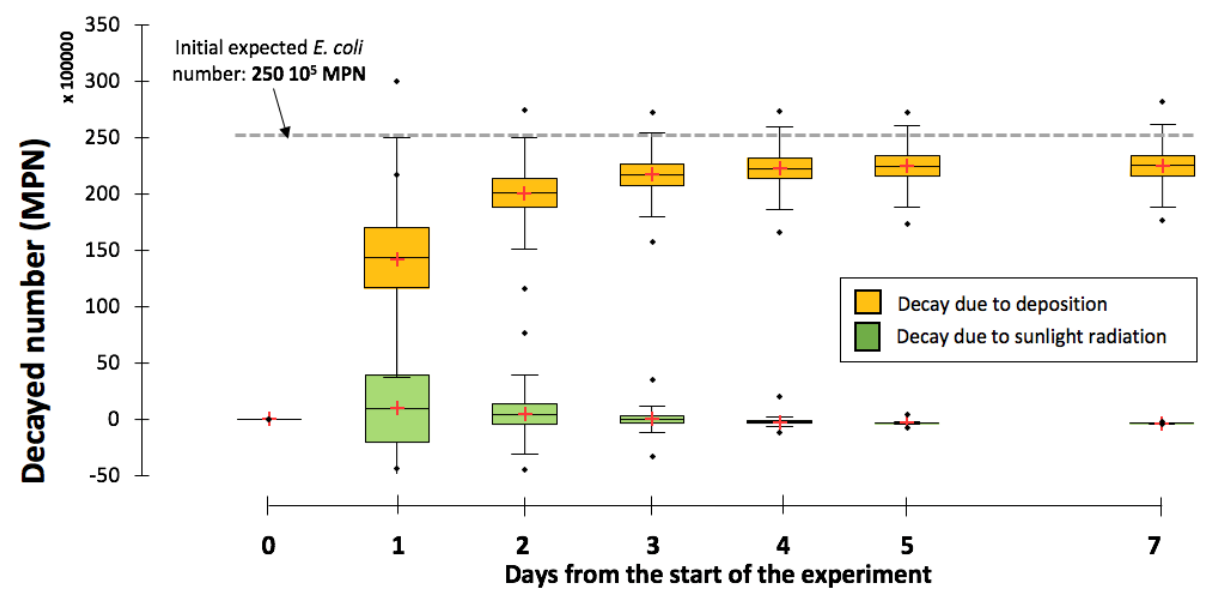

Figure 5. Temporal variations of estimated decayed E. coli number (MPN) due to particle deposition (yellow boxplots) and to solar radiation (green boxplots). The red crosses indicate the means, and the central horizontal bars are the medians. The lower and upper limits of the box are the first and third quartiles, respectively. The lower and upper lines of the boxes are the 10th and 90th percentiles, respectively.

\section{Discussion}

Most studies on factors impacting E. coli in the environment have been carried out in laboratory conditions $[41,42,56,57]$. No comparable in situ studies for wetland ecosystems 
in a tropical humid context, such as that of the montane northern Lao PDR presented in this paper, were found in the scientific literature. This experiment provided an opportunity to study the factors controlling the apparent decay rates of E. coli in a tropical headwater wetland: (i) E. coli concentrations in the Houay Pano stream were usually high (mean initial concentration in this study $>400,000 \mathrm{MPN} 100 \mathrm{~mL}^{-1}$ ) and changes in concentration along the incubation period could therefore be easily observed; (ii) the wetland configuration allowed installing 15 mesocosms to study the effect of both the natural solar radiation, and the suspended particles deposition; (iii) the artificial resuspension process, prior to each sample collection allowed us to access the dynamics of deposited bacteria in the bottom sediment. Even though the multiple processes are more complex and interactive under natural conditions, the outcomes from the semi-controlled environmental conditions of our study are important for determining the effect and the relative importance of the two factors tested here, particle deposition and solar radiation, on the apparent decay rates.

\subsection{Particle Attachment Effect on E. coli Apparent Decay Rates}

In our work, particle-attached bacteria predominated in all mesocosms during the experiment, with a mean of $97 \% \pm 6 \%$ in RD; $99 \% \pm 3 \%$ in RL; $91 \% \pm 22 \%$ in DL; and $98 \% \pm 4 \%$ in DD. It is interesting to note that both [TSS] and turbidity were strongly correlated (Spearman correlation, $p<0.05)$ with $[E . \text { coli }]_{\text {total }}$ in RL $(r=0.87 ; \mathrm{r}=0.79$, respectively), DL $(r=0.67 ; r=0.72$, respectively), and $\mathrm{DD}(\mathrm{r}=0.88 ; \mathrm{r}=0.93$, respectively). On the contrary, [TSS] and turbidity were not significantly correlated with [E. coli $]_{\text {total }}$ in RD. It is well documented that bacteria, including E. coli, tend to be attached to particles within the water column [69-71], and several studies have identified positive correlations between TSS and E. coli concentration in tropical aquatic systems [64,72,73]. We observed that $\mathrm{k}$ values for free-living E. coli $\left(\mathrm{k}=1.53\right.$ day $^{-1}$ in DL; 1.36 day $^{-1}$ in DD; 0.49 day $^{-1}$ in $\mathrm{RL} ; 0.28$ day $^{-1}$ in RD) were higher for the particle-attached E. coli $\left(\mathrm{k}=1.41\right.$ day $^{-1}$ in DL; 1.18 day $^{-1}$ in DD; 1.20 day $^{-1}$ in RL; -0.15 day $^{-1}$ in RD). Yet, our [DOC] measurements in the water column, over the incubation period, show that organic matter was not a factor limiting the survival of bacteria inside the mesocosms (Figure 4e,f). The rapid reduction of free-living E. coli concentration from the water column in the mesocosms (Figure $4 \mathrm{~g}$,h) can be partly attributed to predation-related mortality $[54,74,75]$, as also stated in a study on lake water mesocosms in Germany [76]. Our results are in alignment with previous studies that reported significantly lower decay rates for bacteria associated with particles as opposed to free-living E. coli $[50,77]$. The association of FIB with particles in water can improve their survival by providing protection against the bactericidal effects of light [36,43,78-82]. A study investigating the effect of particle size on E. coli solar inactivation [42], showed that $91 \%$ of $E$. coli were associated with particle sizes $<12 \mu \mathrm{m}$, and that they were inactivated on average two times faster than those associated with the larger particle fraction between 12 and $63 \mu \mathrm{m}$. In Houay Pano catchment, during low intensity floods, the median size of suspended particles ranged between 6 and $24 \mu \mathrm{m}$ due to the particle sorting process and reduced water velocity within the wetland [60]. The wetland hydrodynamic configuration, given the limited hydraulic radius of the wetted area, low flow velocity, and low slope, can significantly favor particle deposition processes. Therefore, suspended particles, not only provide benefits to bacteria, but also are vectors for bacterial transport settling in bottom sediment [83] thereby providing a new environment for the cells.

\subsection{Deposition Effect on E. coli Apparent Decay Rates}

E. coli concentration in mesocosms left to deposition (DL and DD) decreased faster than in mesocosms exposed to daily resuspension (RL and RD) (Figure 4i,j). The decrease in total E. coli concentration in the water column in the absence of resuspension (DD and DL) might be due to the process of bacterial trapping by sediment deposition, along with the process of bacterial mortality. Under deposition conditions, there was a $96 \%$ decrease in the total initial E. coli concentration in the first $24 \mathrm{~h}$ following the incubation, emphasizing 
the importance of the deposition process on the reduction of E. coli concentration within the water column. These findings are consistent with a previous study conducted in the Houay Pano catchment [5], which reported a rapid drop in the concentrations [TSS] and particleattached E. coli within a short distance $(100 \mathrm{~m})$ downstream from the wetland. These observations [5] along with other reports [84] have also pointed out the filtering effect of wetlands, where aquatic plants can trap 30 to $70 \%$ of the suspended sediments. Therefore, it is likely that the headwater wetland represents a long-term sediment accumulation zone within the Houay Pano catchment [61].

In re-suspension treatments (RL and RD), the observed slight increase of E. coli concentration (Figure $4 i, j)$ reflects the balance between bacterial mortality and bacterial survival and / or growth in deposited sediments. Another study found that FIB decay rates were much lower in sediments than in the water column, indicating a potentially important role of sediments in harboring FIB populations $[50,64]$. Recent studies have demonstrated that bottom sediments can act as a major reservoir of FIB harboring much more concentrated populations of microorganisms than the overlying water column [85-88]. Further, bottom sediments can be mobilized by resuspension events, contributing to the bacterial input to surface waters $[26,48,89]$. In a recent microcosm study [90], E. coli concentration increased in clayey sediment during the first 8 days of incubation before starting to decrease until the end of the experiment which lasted for 57 days. Our results are also comparable to that of a 50-day microcosm study of Geneva lake water contaminated with freshwater sediments [57] that found a growth phase between the 5th and 12th days of incubation and low decay rates of 0.29 day $^{-1}$ in fine-textured sediments containing higher levels of organic matter. In the present study, the results of the RD treatment allowed to access E. coli in bottom sediments, suggesting that $E$. coli can survive, explaining the stable E. coli concentration observed during the first 5 days in RL and RD. These results must be qualified given the higher uncertainty compared to the other treatments (Figure S3). In future studies, a longer period of observation of at least 30 days should be privileged, to allow a better understanding of the potential E. coli survival in secondary habitats, in order to better mitigate their potential impact on public health. Moreover, the utility of $E$. coli as an environmental FIB might be challenged given its likely ability to persist and grow under certain conditions likely to be found in tropical contexts $[28,91]$.

\subsection{Solar Radiation Effect on E. coli Apparent Decay Rates}

The total E. coli apparent decay rates k obtained in the mesocosms exposed to solar radiation ranged between 0.49 day $^{-1}(\mathrm{RL})$ and 1.43 day $^{-1}(\mathrm{DL})$, whereas in covered mesocosms, it ranged between -0.14 day $^{-1}$ (RD) and 1.19 day $^{-1}$ (DD) (Table 1). These results can be compared to the values of $k$ obtained in a study carried out by [64] in the Red River in northern Vietnam, where the total $E$. coli decay rates under dark conditions ranged from 0.01 to 1.13 day $^{-1}$. Hence, in the present work, a higher $\mathrm{k}$ was noted in RL when compared to $\mathrm{RD}$, and it was also noted in DL when compared to DD. Several studies showed that solar radiation causes inactivation of a wide range of microorganisms present in water [80,92]. In particular, the U.V.-B part of the spectrum causes direct photo-biological damages degrading the nucleic acids within bacteria $[36,93,94]$. Both previous field observations and laboratory experiments have pointed out the importance of solar radiation in reducing FIB concentrations in surface waters. Research focusing on the impacts of solar radiation on FIB like E. coli have been mainly conducted in marine aquatic environments [36,78,95]. In a study carried out in subtropical coastal ecosystems [34], light intensity was identified as the most significant factor affecting $E$. coli decay rate as compared to dark conditions. In fact, the in situ bacterial decay rates found in [34], ranged between 1.3 and 5.1 day $^{-1}$ and increased significantly with light intensity. Few studies only deal with freshwater ecosystems [36,41]. For instance, in a study conducted in Lake Michigan, USA [40], an exponential decrease in $E$. coli counts was noted in the upper $90 \mathrm{~cm}$ of the lake during sunny days, contrasting with the much weaker E. coli inactivation noted during cloudy days. 
In shallow aquatic ecosystems, sunlight penetration into the water column can be considered among the most important factors in bacterial inactivation and decline [41]. However, tropical wetlands are often characterized by dense vegetation thereby limiting sunlight penetration [96]. Our study showed the attenuation of solar radiations by dense vegetation within the wetland, preventing most of the light from reaching the water column (Figures 2 and S1). Moreover, it seems important to take into account the impact of vegetation type and density on flow reduction within wetlands, which further impacts bacterial transport and fate.

While solar radiation can significantly affect $E$. coli survival, UV radiation can be scattered by TSS [42,82] in highly turbid water following a resuspension event or surface runoff, especially during the rainy season in tropical environments. In a study conducted in estuarine and coastal waters in the UK [95], the bacterial decay in highly turbid water (>200 NTU) exposed to solar radiation did not differ from their decay rates observed under dark conditions. When assessing the effect of solar radiation on E. coli reduction, it is therefore imperative to take into account the effect of TSS in the water column.

\subsection{Relative Effects of Solar Radiation and Deposition on E. coli Apparent Decay Rates}

In order to identify the relative importance of the two studied factors, namely solar radiation and deposition process, in the apparent bacterial decay, we compared the percentages of E. coli stock variations attributed to each factor at each sampling date. A comparison of DL with DD indicates that the deposition process accounts for an average of $92 \%$ of the decayed bacterial number over the experiment duration, while $2 \%$ corresponds to the effect of solar radiation (Figure 5 and Figure S2). In DL and DD mesocosms, the T90 value was similar when exposed to solar radiation (DL, $38 \mathrm{~h}$ ) and when in dark (DD, $47 \mathrm{~h}$ ), whereas in RL and RD mesocosms, the $T_{90}$ value was $111 \mathrm{~h}$ and $391 \mathrm{~h}$ respectively (Table 2). A study in the UK [95] showed lower $\mathrm{T}_{90}$ values of $24.8 \mathrm{~h}$ in low-turbidity estuarine waters in dark conditions, and $6 \mathrm{~h}$ when exposed to solar radiation. Although a large number of studies have been highlighting the solar radiation effect on E. coli $\mathrm{T}_{90}[38,97]$, it is also imperative to consider other predominant factors like TSS dynamics as well as deposition and resuspension processes when investigating bacterial decay rates in aquatic ecosystems such as tropical wetlands, which are common landscape features especially in the mountainous area of northern Lao PDR and in the tropical South-East Asia in general [11]. Deposition processes occurring in aquatic ecosystems are rather complex, influenced by multiple factors such as TSS concentrations, size, and settling velocity [98], presence of dense vegetation [99], as well as hydrodynamic conditions (stream flow velocity, slope gradient, and turbulence in water column) [100]. The importance of E. coli reduction due to deposition depends largely on whether the bacteria are associated to particles which are vectors for vertical migration of pathogens within the water column [83]. In our study, more than $91 \%$ of total E. coli were attached to particles in all mesocosms over the incubation period. Our findings are consistent with the studies that found that deposition process is identified as a key process involved in pathogen reduction and is widely used to decontaminate water in constructed wetlands. At local scales, wetlands have been shown to contribute to the regulating ecosystem service of reducing waterborne pollutant loading to downstream environments.

Wetlands act as a natural sanitation system [101], providing a nature-based solution for water quality improvement. Over the last century, constructed wetlands have been designed to include physical, biological, and chemical processes similar to those occurring in natural wetlands. Today, constructed wetlands are recognized as a suitable alternative wastewater treatment technology in many countries [102-106]. An accurate understanding of FIB controlling factors in lentic systems like wetlands is fundamental for a better management of natural as well as constructed wetlands, in the perspective of the effective conservation of the valuable ecosystem services that they deliver. Such an improved understanding is especially critical in rural areas of developing tropical countries whose populations directly rely on untreated surface waters [7]. 


\section{Conclusions}

This study aimed to determine E. coli apparent decay rates, i.e., the net equilibrium between the increase and the decrease in E. coli concentration due to possible bacteria growth, bacteria mortality, and deposition process, in a tropical headwater wetland. The environmental variables assessed were solar radiation and suspended particles deposition.

- Particle-attached bacteria prevailed in all mesocosms over the incubation period: over $91 \%$ of total E. coli were attached to particles.

- Apparent decay rates of free-living bacteria were higher than apparent decay rates of particle-attached bacteria in all mesocosms.

- Apparent decay rates of total E. coli concentration in mesocosms left to deposit ranged from $1.43 \pm 0.15$ to $1.17 \pm 0.13$ day $^{-1}$ when exposed to light and dark conditions, respectively. Apparent decay rates in mesocosms stirred prior to sampling ranged from $0.50 \pm 0.15$ to $-0.14 \pm 0.37$ day $^{-1}$ when exposed to light and dark conditions, respectively.

- Deposition accounted for an average of $92 \%$ of the estimated E. coli stock reduction in the water column, while $2 \%$ of the estimated E. coli stock reduction was due to the exposure to solar radiation.

- $\quad$ By resuspending the bottom sediment prior to sample collecting in RD mesocosms, we mobilized the deposited E. coli that showed stable concentration during the first 5 days of the experiment, suggesting a survival of bacterial population in bed sediments.

The improved understanding of factors controlling E. coli fate should be exploited to further develop practical strategies for a better management of natural ecosystems like wetlands. This work brings insights to improve modeling approaches in tropical contexts by providing a range of bacterial decay rates to parameterize hydrological and water quality models.

Supplementary Materials: The following are available online at https://www.mdpi.com/article/10.3 390/w13152068/s1, Figure S1. (a) Photo of the Napier grass and solar sensor installed in the wetland of Houay Pano catchment, northern Lao PDR; (b) diagram of the solar sensors installed at different heights ( $380 \mathrm{~cm}, 100 \mathrm{~cm}, 3 \mathrm{~cm}$, and inside the mesocosm) to measure the solar radiation attenuation by Napier grass during two days (24 and 25 October 2020) in the wetland of the Houay Pano catchment. The pyranometers used to measure solar radiation at $380 \mathrm{~cm}$ height: SP110 (Campbell CS300); at $100 \mathrm{~cm}$ height: RG100 Solems; at $3 \mathrm{~cm}$ height: Li200X (LI-COR PY34392); and inside covered top mesocosm: RG100 Solems. Figure S2. Stacked area graph showing the average percentage of the estimated fraction of decayed E. coli at daily time steps during the experiment: the grey area corresponds to the decay fraction due to deposition; the yellow area corresponds to the decay fraction due to solar radiation, and the blue area is the residual fraction of decayed E. coli. Figure S3. Plot of $\operatorname{Ln}\left(C_{t} / C_{i}\right)$ versus time in days where $C_{t}$ is the measured concentration of total $E$. coli at time $t$ in MPN $100 \mathrm{~mL}^{-1}, \mathrm{C}_{\mathrm{i}}$ is the measured initial concentration of total E. coli in MPN $100 \mathrm{~mL}^{-1}$ for the mesocosms installed in the headwater wetland of the Houay Pano catchment, northern Lao PDR, from August 9 to August 16, 2019. RD: Resuspension-Dark; RL: Resuspension-Light; DD: Deposition-Dark; DL: Deposition-Light. Dotted lines represent 95\% confidence interval and continuous lines represent 95\% prediction interval.

Author Contributions: Conceptualization, P.N., L.B. and O.R.; methodology, P.N., L.B. and O.R.; investigation, P.N., L.B., A.P.-B., C.T., N.G., P.S., N.S., K.L., B.S., E.J.R.-N. and O.R.; data curation, P.N., L.B., N.G., E.J.R.-N., Y.M. and O.R.; writing—original draft preparation, P.N.; writing-review and editing, L.B., A.P.-B, N.G., N.S., E.J.R.-N., A.P. and O.R.; visualization, P.N.; supervision, L.B. and O.R.; project administration, L.B. All authors have read and agreed to the published version of the manuscript.

Funding: This work was supported by the French national grant EC2CO-Biohefect/Ecodyn//Dril/ MicrobiEn (NARIBACT). The APC was funded by M-TROPICS.

Data Availability Statement: The authors confirm that the data supporting the findings of this study are available open access on DataSuds https:/ / doi.org/10.23708/E52ZTX, accessed on 20 June 2021. 
Acknowledgments: The authors sincerely thank the Lao Department of Agricultural Land Management (DALaM) for its support, including granting the permission for field access, and the M-TROPICS Critical Zone Observatory (https:/ / mtropics.obs-mip.fr/, accessed on 20 June 2021), which belongs to the French Research Infrastructure OZCAR (http:/ / www.ozcar-ri.org/, accessed on 20 June 2021), for data access.

Conflicts of Interest: The authors declare no conflict of interest. The funders had no role in the design of the study; in the collection, analyses, or interpretation of data; in the writing of the manuscript, or in the decision to publish the results.

\section{References}

1. WHO. Inheriting a Sustainable World? Atlas on Children's Health and the Environment; World Health Organization: Geneva, Switzerland, 2017.

2. UNEPA. A Snapshot of the World's Water Quality: Towards a Global Assessment; United Nations Environment Programme: Nairobi, Kenya, 2016.

3. Prüss-Ustün, A.; Wolf, J.; Bartram, J.; Clasen, T.; Cumming, O.; Freeman, M.C.; Gordon, B.; Hunter, P.R.; Medlicott, K.; Johnston, R. Burden of Disease from Inadequate Water, Sanitation and Hygiene for Selected Adverse Health Outcomes: An Updated Analysis with a Focus on Low- and Middle-Income Countries. Int. J. Hyg. Environ. Health 2019, 222, 765-777. [CrossRef] [PubMed]

4. WHO/UNICEF Joint Water Supply and Sanitation Monitoring Programme and World Health Organization. Progress on Sanitation and Drinking Water: 2015 Update and MDG Assessment; World Health Organization: Geneva, Switzerland, 2015.

5. Ribolzi, O.; Cuny, J.; Sengsoulichanh, P.; Mousquès, C.; Soulileuth, B.; Pierret, A.; Huon, S.; Sengtaheuanghoung, O. Land Use and Water Quality along a Mekong Tributary in Northern Lao P.D.R. Environ. Manag. 2011, 47, 291-302. [CrossRef] [PubMed]

6. Ribolzi, O.; Evrard, O.; Huon, S.; Rochelle-Newall, E.; Henri-des-Tureaux, T.; Silvera, N.; Thammahacksac, C.; Sengtaheuanghoung, O. Use of Fallout Radionuclides $(7 \mathrm{Be}, 210 \mathrm{~Pb})$ to Estimate Resuspension of Escherichia coli from Streambed Sediments during Floods in a Tropical Montane Catchment. Environ. Sci. Pollut. Res. 2016, 23, 3427-3435. [CrossRef] [PubMed]

7. Boithias, L.; Choisy, M.; Souliyaseng, N.; Jourdren, M.; Quet, F.; Buisson, Y.; Thammahacksa, C.; Silvera, N.; Latsachack, K.; Sengtaheuanghoung, O.; et al. Hydrological Regime and Water Shortage as Drivers of the Seasonal Incidence of Diarrheal Diseases in a Tropical Montane Environment. PLoS Negl. Trop. Dis. 2016, 10, e0005195. [CrossRef]

8. Johnston, C.A. Sediment and Nutrient Retention by Freshwater Wetlands: Effects on Surface Water Quality. Crit. Rev. Environ. Control 1991, 21, 491-565. [CrossRef]

9. Mander, Ü.; Mitsch, W.J. Pollution Control by Wetlands. Ecol. Eng. 2009, 35, 153-158. [CrossRef]

10. Arias, M.E.; Holtgrieve, G.W.; Ngor, P.B.; Dang, T.D.; Piman, T. Maintaining Perspective of Ongoing Environmental Change in the Mekong Floodplains. Curr. Opin. Environ. Sustain. 2019, 37, 1-7. [CrossRef]

11. MacAlister, C.; Mahaxay, M. Mapping Wetlands in the Lower Mekong Basin for Wetland Resource and Conservation Management Using Landsat ETM Images and Field Survey Data. J. Environ. Manag. 2009, 90, 2130-2137. [CrossRef]

12. Berg, H.; Ekman Söderholm, A.; Söderström, A.S.; Tam, N.T. Recognizing Wetland Ecosystem Services for Sustainable Rice Farming in the Mekong Delta, Vietnam. Sustain. Sci. 2017, 12, 137-154. [CrossRef]

13. Grundy-Warr, C.; Andrews, R.H.; Sithithaworn, P.; Petney, T.N.; Sripa, B.; Laithavewat, L.; Ziegler, A.D. Raw Attitudes, Wetland Cultures, Life-Cycles: Socio-Cultural Dynamics Relating to Opisthorchis Viverrini in the Mekong Basin. Parasitol. Int. 2012, 61, 65-70. [CrossRef]

14. Zedler, J.B.; Kercher, S. WETLAND RESOURCES: Status, Trends, Ecosystem Services, and Restorability. Annu. Rev. Environ. Resour. 2005, 30, 39-74. [CrossRef]

15. Millennium Ecosystem Assessment. Ecosystems and Human Well-Being: Synthesis; Island Press: Washington, DC, USA, 2005.

16. Brauman, K.A.; Daily, G.C.; Duarte, T.K.E.O.; Mooney, H.A. The Nature and Value of Ecosystem Services: An Overview Highlighting Hydrologic Services. Annu. Rev. Environ. Resour. 2007, 32, 67-98. [CrossRef]

17. USEPA (U.S. Environmental Protection Agency). Connectivity of Streams and Wetlands to Downstream Waters: A Review and Synthesis of the Scientific Evidence; US Environmental Protection Agency: Washington, DC, USA, 2015.

18. Lane, C.R.; Leibowitz, S.G.; Autrey, B.C.; LeDuc, S.D.; Alexander, L.C. Hydrological, Physical, and Chemical Functions and Connectivity of Non-Floodplain Wetlands to Downstream Waters: A Review. J. Am. Water Resour. Assoc. 2018, 54, 346-371. [CrossRef]

19. Krecek, J.; Haigh, M. Environmental Role of Wetlands in Headwaters; Springer Science \& Business Media: Dordrecht, The Netherlands, 2006; Volume 63.

20. Alexander, R.B.; Boyer, E.W.; Smith, R.A.; Schwarz, G.E.; Moore, R.B. The Role of Headwater Streams in Downstream Water Quality1. JAWRA J. Am. Water Resour. Assoc. 2007, 43, 41-59. [CrossRef] [PubMed]

21. Colvin, S.A.R.; Sullivan, S.M.P.; Shirey, P.D.; Colvin, R.W.; Winemiller, K.O.; Hughes, R.M.; Fausch, K.D.; Infante, D.M.; Olden, J.D.; Bestgen, K.R.; et al. Headwater Streams and Wetlands Are Critical for Sustaining Fish, Fisheries, and Ecosystem Services. Fisheries 2019, 44, 73-91. [CrossRef]

22. Herrera, D.; Ellis, A.; Fisher, B.; Golden, C.D.; Johnson, K.; Mulligan, M.; Pfaff, A.; Treuer, T.; Ricketts, T.H. Upstream Watershed Condition Predicts Rural Children's Health across 35 Developing Countries. Nat. Commun. 2017, 8. [CrossRef] [PubMed] 
23. Ishii, S.; Sadowsky, M.J. Escherichia Coli in the Environment: Implications for Water Quality and Human Health. Microbes Environ. 2008, 23, 101-108. [CrossRef] [PubMed]

24. Quin, A.; Jaramillo, F.; Destouni, G. Dissecting the Ecosystem Service of Large-Scale Pollutant Retention: The Role of Wetlands and Other Landscape Features. AMBIO 2015, 44, 127-137. [CrossRef]

25. Knox, A.K.; Dahlgren, R.A.; Tate, K.W.; Atwill, E.R. Efficacy of Natural Wetlands to Retain Nutrient, Sediment and Microbial Pollutants. J. Environ. Qual. 2008, 37, 1837-1846. [CrossRef]

26. Pachepsky, Y.A.; Shelton, D.R. Escherichia Coli and Fecal Coliforms in Freshwater and Estuarine Sediments. Crit. Rev. Environ. Sci. Technol. 2011, 41, 1067-1110. [CrossRef]

27. World Health Organization. Guidelines for Drinking-Water Quality, 4th ed.; WHO Chronicle; WHO: Geneva, Switzerland, 2011.

28. Rochelle-Newall, E.; Nguyen, T.M.H.; Le, T.P.Q.; Sengtaheuanghoung, O.; Ribolzi, O. A Short Review of Fecal Indicator Bacteria in Tropical Aquatic Ecosystems: Knowledge Gaps and Future Directions. Front. Microbiol. 2015, 6, 308. [CrossRef] [PubMed]

29. Anderson, K.L.; Whitlock, J.E.; Harwood, V.J. Persistence and Differential Survival of Fecal Indicator Bacteria in Subtropical Waters and Sediments. Appl. Environ. Microbiol. 2005, 71, 3041-3048. [CrossRef] [PubMed]

30. Naganandhini, S.; Kennedy, Z.J.; Uyttendaele, M.; Balachandar, D. Persistence of Pathogenic and Non-Pathogenic Escherichia Coli Strains in Various Tropical Agricultural Soils of India. PLoS ONE 2015, 10. [CrossRef]

31. Isobe, K.O.; Tarao, M.; Chiem, N.H.; Minh, L.Y.; Takada, H. Effect of Environmental Factors on the Relationship between Concentrations of Coprostanol and Fecal Indicator Bacteria in Tropical (Mekong Delta) and Temperate (Tokyo) Freshwaters. Appl. Environ. Microbiol. 2004, 70, 814-821. [CrossRef]

32. Petersen, F.; Hubbart, J.A. Physical Factors Impacting the Survival and Occurrence of Escherichia Coli in Secondary Habitats. Water 2020, 12, 1796. [CrossRef]

33. Solo-Gabriele, H.M.; Wolfert, M.A.; Desmarais, T.R.; Palmer, C.J. Sources of Escherichia Coli in a Coastal Subtropical Environment. Appl. Environ. Microbiol. 2000, 66, 230-237. [CrossRef]

34. Chan, Y.M.; Thoe, W.; Lee, J.H.W. Field and Laboratory Studies of Escherichia Coli Decay Rate in Subtropical Coastal Water. J. Hydro-Environ. Res. 2015, 9, 1-14. [CrossRef]

35. Fujiokal, R.S.; Narikawa, O.T. Effect of Sunlight on Enumeration of Indicator Bacteria Under Field Conditions. Appl. Environ. Microbiol. 1982, 44, 395-401. [CrossRef] [PubMed]

36. Sinton, L.W.; Hall, C.H.; Lynch, P.A.; Davies-Colley, R.J. Sunlight Inactivation of Fecal Indicator Bacteria and Bacteriophages from Waste Stabilization Pond Effluent in Fresh and Saline Waters. Appl. Environ. Microbiol. 2002, 68, 1122-1131. [CrossRef] [PubMed]

37. Nelson, K.L.; Boehm, A.B.; Davies-Colley, R.J.; Dodd, M.C.; Kohn, T.; Linden, K.G.; Liu, Y.; Maraccini, P.A.; McNeill, K.; Mitch, W.A.; et al. Sunlight-Mediated Inactivation of Health-Relevant Microorganisms in Water: A Review of Mechanisms and Modeling Approaches. Environ. Sci. Process. Impacts 2018, 20, 1089-1122. [CrossRef]

38. Jozić, S.; Morović, M.; Šolić, M.; Krstulović, N.; Ordulj, M. Effect of Solar Radiation, Temperature and Salinity on the Survival of Two Different Strains of Escherichia Coli. Fresenius Environ. Bull. 2014, 23, 1852-1859.

39. Pienaar, J.A.; Singh, A.; Barnard, T.G. The Viable but Non-Culturable State in Pathogenic Escherichia Coli: A General Review. Afr. J. Lab. Med. 2016, 5. [CrossRef] [PubMed]

40. Whitman, R.L.; Nevers, M.B.; Korinek, G.C.; Byappanahalli, M.N. Solar and Temporal Effects on Escherichia Coli Concentration at a Lake Michigan Swimming Beach. Appl. Environ. Microbiol. 2004, 70, 4276-4285. [CrossRef]

41. Maraccini, P.A.; Mattioli, M.C.M.; Sassoubre, L.M.; Cao, Y.; Griffith, J.F.; Ervin, J.S.; Van De Werfhorst, L.C.; Boehm, A.B. Solar Inactivation of Enterococci and Escherichia Coli in Natural Waters: Effects of Water Absorbance and Depth. Environ. Sci. Technol. 2016, 50, 5068-5076. [CrossRef] [PubMed]

42. Walters, E.; Graml, M.; Behle, C.; Horn, H.; Müller, E. Influence of Particle Association and Suspended Solids on UV Inactivation of Fecal Indicator Bacteria in an Urban River. Water Air Soil Pollut. 2014, 225, 1822. [CrossRef]

43. Perkins, T.L.; Perrow, K.; Rajko-Nenow, P.; Jago, C.F.; Jones, D.L.; Malham, S.K.; McDonald, J.E. Decay Rates of Faecal Indicator Bacteria from Sewage and Ovine Faeces in Brackish and Freshwater Microcosms with Contrasting Suspended Particulate Matter Concentrations. Sci. Total Environ. 2016, 572, 1645-1652. [CrossRef] [PubMed]

44. Karim, M.R.; Manshadi, F.D.; Karpiscak, M.M.; Gerba, C.P. The Persistence and Removal of Enteric Pathogens in Constructed Wetlands. Water Res. 2004, 38, 1831-1837. [CrossRef] [PubMed]

45. O'Geen, A.T.; Bianchi, M.L. Using Wetlands to Remove Microbial Pollutants from Farm Discharge Water. Agric. Nat. Resour. Publ. 2015, 1-11. [CrossRef]

46. Howell, J.M.; Coyne, M.S.; Cornelius, P.L. Effect of Sediment Particle Size and Temperature on Fecal Bacteria Mortality Rates and the Fecal Coliform/Fecal Streptococci Ratio. J. Environ. Qual. 1996, 25, 1216-1220. [CrossRef]

47. Boutilier, L.; Jamieson, R.; Gordon, R.; Lake, C.; Hart, W. Adsorption, Sedimentation, and Inactivation of E. Coli within Wastewater Treatment Wetlands. Water Res. 2009, 43, 4370-4380. [CrossRef] [PubMed]

48. Boithias, L.; Ribolzi, O.; Lacombe, G.; Thammahacksa, C.; Silvera, N.; Latsachack, K.; Soulileuth, B.; Viguier, M.; Auda, Y.; Robert, E.; et al. Quantifying the Effect of Overland Flow on Escherichia Coli Pulses during Floods: Use of a Tracer-Based Approach in an Erosion-Prone Tropical Catchment. J. Hydrol. 2021, 594, 125935. [CrossRef]

49. Blaustein, R.A.; Pachepsky, Y.; Hill, R.L.; Shelton, D.R.; Whelan, G. Escherichia Coli Survival in Waters: Temperature Dependence. Water Res. 2013, 47, 569-578. [CrossRef] 
50. Craig, D.L.; Fallowfield, H.J.; Cromar, N.J. Use of Microcosms to Determine Persistence of Escherichia coli in Recreational Coastal Water and Sediment and Validation with in situ Measurements. J. Appl. Microbiol. 2004, 96, 922-930. [CrossRef]

51. Shelton, D.R.; Pachepsky, Y.A.; Kiefer, L.A.; Blaustein, R.A.; McCarty, G.W.; Dao, T.H. Response of Coliform Populations in Streambed Sediment and Water Column to Changes in Nutrient Concentrations in Water. Water Res. 2014, 59, 316-324. [CrossRef] [PubMed]

52. Gregory, L.F.; Karthikeyan, R.; Aitkenhead-Peterson, J.A.; Gentry, T.J.; Wagner, K.L.; Harmel, R.D. Nutrient Loading Impacts on Culturable E. Coli and Other Heterotrophic Bacteria Fate in Simulated Stream Mesocosms. Water Res. 2017, 126, 442-449. [CrossRef]

53. Bordalo, A.A.; Onrassami, R.; Dechsakulwatana, C. Survival of Faecal Indicator Bacteria in Tropical Estuarine Waters (Bangpakong River, Thailand). J. Appl. Microbiol. 2002, 93, 864-871. [CrossRef] [PubMed]

54. Korajkic, A.; Wanjugi, P.; Harwood, V.J. Indigenous Microbiota and Habitat Influence Escherichia Coli Survival More than Sunlight in Simulated Aquatic Environments. Appl. Environ. Microbiol. 2013, 79, 5329-5337. [CrossRef]

55. Boithias, L.; Auda, Y.; Audry, S.; Bricquet, J.; Chanhphengxay, A.; Chaplot, V.; Rouw, A.; Tureaux, T.H.; Huon, S.; Janeau, J.; et al. The Multiscale TROPIcal CatchmentS Critical Zone Observatory M-TROPICS Dataset II: Land Use, Hydrology and Sediment Production Monitoring in Houay Pano, Northern Lao PDR. Hydrol. Process. 2021, 35, e14126. [CrossRef]

56. Wang, Y.; Pandey, P.; Zheng, Y.; Atwill, E.R.; Pasternack, G. Particle Attached and Free Floating Pathogens Survival Kinetics under Typical Stream and Thermal Spring Temperature Conditions. AMB Express 2018, 8, 1-14. [CrossRef] [PubMed]

57. Haller, L.; Amedegnato, E.; Poté, J.; Wildi, W. Influence of Freshwater Sediment Characteristics on Persistence of Fecal Indicator Bacteria. Water Air Soil Pollut. 2009, 203, 217-227. [CrossRef]

58. Gaillardet, J.; Braud, I.; Hankard, F.; Anquetin, S.; Bour, O.; Dorfliger, N.; de Dreuzy, J.R.; Galle, S.; Galy, C.; Gogo, S.; et al. OZCAR: The French Network of Critical Zone Observatories. Vadose Zone J. 2018, 17, 180067. [CrossRef]

59. Ribolzi, O.; Lacombe, G.; Pierret, A.; Robain, H.; Sounyafong, P.; de Rouw, A.; Soulileuth, B.; Mouche, E.; Huon, S.; Silvera, N.; et al. Interacting Land Use and Soil Surface Dynamics Control Groundwater Outflow in a Montane Catchment of the Lower Mekong Basin. Agric. Ecosyst. Environ. 2018, 268, 90-102. [CrossRef]

60. Huon, S.; Evrard, O.; Gourdin, E.; Lefèvre, I.; Bariac, T.; Reyss, J.L.; Henry des Tureaux, T.; Sengtaheuanghoung, O.; Ayrault, S.; Ribolzi, O. Suspended Sediment Source and Propagation during Monsoon Events across Nested Sub-Catchments with Contrasted Land Uses in Laos. J. Hydrol. Reg. Stud. 2017, 9, 69-84. [CrossRef]

61. Huon, S.; de Rouw, A.; Bonté, P.; Robain, H.; Valentin, C.; Lefèvre, I.; Girardin, C.; Le Troquer, Y.; Podwojewski, P.; Sengtaheuanghoung, O. Long-Term Soil Carbon Loss and Accumulation in a Catchment Following the Conversion of Forest to Arable Land in Northern Laos. Agric. Ecosyst. Environ. 2013, 169, 43-57. [CrossRef]

62. Hjulstrom, F. Studies of the Morphological Activity of Rivers as Illustrated by the River Fyris, Bulletin. Geol. Inst. Upsalsa 1935, $25,221-527$.

63. Huon, S.; Ribolzi, O.; Aubry, E.; Soulileuth, B.; Longchamp, M.; Angeli, O.; Sengtaheuanghoung, N. Iron and Manganese Concentration Levels in Watercress Cultivated within the Main Stream of the Houay Pano Catchment, Northern Lao PDR. Lao J. Agric. For. 2008, 17, 113-128.

64. Nguyen, H.T.M.; Le, Q.T.P.; Garnier, J.; Janeau, J.L.; Rochelle-Newall, E. Seasonal Variability of Faecal Indicator Bacteria Numbers and Die-off Rates in the Red River Basin, North Viet Nam. Sci. Rep. 2016, 6, 21644. [CrossRef]

65. Lebaron, P.; Henry, A.; Lepeuple, A.S.; Pena, G.; Servais, P. An Operational Method for the Real-Time Monitoring of E. Coli Numbers in Bathing Waters. Mar. Pollut. Bull. 2005, 50, 652-659. [CrossRef]

66. Chick, H. An Investigation of the Laws of Disinfection. J. Hyg. 1908, 8, 92-158. [CrossRef]

67. Ribolzi, O.; Andrieux, P.; Valles, V.; Bouzigues, R.; Bariac, T.; Voltz, M. Contribution of Groundwater and Overland Flows to Storm Flow Generation in a Cultivated Mediterranean Catchment. Quantification by Natural Chemical Tracing. J. Hydrol. 2000, 233, 241-257. [CrossRef]

68. Nakhle, P.; Boithias, L.; Pando-Bahuon, A.; Thammahacksa, C.; Gallion, N.; Sounyafong, P.; Silvera, N.; Latsachack, K.; Soulileuth, B.; Rochelle-Newall, E.; et al. Concentrations of Escherichia Coli, Total Suspended Sediment, and Dissolved Organic Carbon, Turbidity, and Environmental Variables Measured in 2019 in a Headwater Wetland in The Houay Pano Catchment, Northern Lao PDR. Available online: https: / / dataverse.ird.fr/dataset.xhtml?persistentId=doi:10.23708/E52ZTX (accessed on 29 June 2021).

69. Oliver, D.M.; Clegg, C.D.; Heathwaite, A.L.; Haygarth, P.M. Preferential Attachment of Escherichia Coli to Different Particle Size Fractions of an Agricultural Grassland Soil. Water Air Soil Pollut. 2007, 185, 369-375. [CrossRef]

70. Malham, S.K.; Rajko-Nenow, P.; Howlett, E.; Tuson, K.E.; Perkins, T.L.; Pallett, D.W.; Wang, H.; Jago, C.F.; Jones, D.L.; McDonald, J.E. The Interaction of Human Microbial Pathogens, Particulate Material and Nutrients in Estuarine Environments and Their Impacts on Recreational and Shellfish Waters. Environ. Sci. Process. Impacts 2014, 16, 2145-2155. [CrossRef]

71. Petersen, F.; Hubbart, J.A. Quantifying Escherichia Coli and Suspended Particulate Matter Concentrations in a Mixed-Land Use Appalachian Watershed. Water 2020, 12, 532. [CrossRef]

72. Nakhle, P.; Ribolzi, O.; Boithias, L.; Rattanavong, S.; Auda, Y.; Sayavong, S.; Zimmermann, R.; Soulileuth, B.; Pando, A.; Thammahacksa, C.; et al. Effects of Hydrological Regime and Land Use on In-Stream Escherichia Coli Concentration in the Mekong Basin, Lao PDR. Sci. Rep. 2021, 11, 3460. [CrossRef] [PubMed] 
73. Byamukama, D.; Mach, R.L.; Kansiime, F.; Manafi, M.; Farnleitner, A.H. Discrimination Efficacy of Fecal Pollution Detection in Different Aquatic Habitats of a High-Altitude Tropical Country, Using PresumptivE. coliforms, Escherichia Coli, and Clostridium Perfringens Spores. Appl. Environ. Microbiol. 2005, 71, 65-71. [CrossRef] [PubMed]

74. Wanjugi, P.; Harwood, V.J. The Influence of Predation and Competition on the Survival of Commensal and Pathogenic Fecal Bacteria in Aquatic Habitats. Environ. Microbiol. 2013, 15, 517-526. [CrossRef]

75. Davies, C.M.; Bavor, H.J. The Fate of Stormwater-Associated Bacteria in Constructed Wetland and Water Pollution Control Pond Systems. J. Appl. Microbiol. 2000, 89, 349-360. [CrossRef]

76. Brettar, I.; Hoflet, M.G. Influence of Ecosystematic Factors on Survival of Escherichia Coli after Large-Scale Release into Lake Water Mesocosms. Appl. Environ. Microbiol. 1992, 58, 2201-2210. [CrossRef] [PubMed]

77. Davies, C.M.; Long, J.A.H.; Donald, M.; Ashbolt, N.J. Survival of Fecal Microorganisms in Marine and Freshwater Sediments. Appl. Environ. Microbiol. 1995, 61, 1888-1896. [CrossRef] [PubMed]

78. Fujioka, R.S.; Hashimoto, H.H.; Siwak, E.B.; Young', R.H.F. Effect of Sunlight on Survival of Indicator Bacteria in Seawater. Appl. Environ. Microbiol. 1981, 41, 690-696. [CrossRef]

79. Kapuscinski, R.B.; Mitchell, R. Sunlight-Induced Mortality of Viruses and Escherichia Coli in Coastal Seawater. Environ. Sci. Technol. 1983, 17, 1-6. [CrossRef]

80. Davies-Colley, R.J.; Donnison, A.M.; Speed, D.J.; Ross, C.M.; Nagels, J.W. Inactivation of Faecal Indicator Micro-Organisms in Waste Stabilisation Ponds: Interactions of Environmental Factors with Sunlight. Water Res. 1999, 33, 1220-1230. [CrossRef]

81. Farrell, C.; Hassard, F.; Jefferson, B.; Leziart, T.; Nocker, A.; Jarvis, P. Turbidity Composition and the Relationship with Microbial Attachment and UV Inactivation Efficacy. Sci. Total Environ. 2018, 624, 638-647. [CrossRef] [PubMed]

82. Madge, B.A.; Jensen, J.N. Ultraviolet Disinfection of Fecal Coliform in Municipal Wastewater: Effects of Particle Size. Water Environ. Res. 2006, 78, 294-304. [CrossRef] [PubMed]

83. Droppo, I.G.; Liss, S.N.; Williams, D.; Nelson, T.; Jaskot, C.; Trapp, B. Dynamic Existence of Waterborne Pathogens within River Sediment Compartments. Implications for Water Quality Regulatory Affairs. Environ. Sci. Technol. 2009, 43, 1737-1743. [CrossRef]

84. Thornton, C.I.; Abt, S.R.; Clary, W.P. Vegetation influence on small stream siltation. J. Am. Water Resour. Assoc. 2007, 33, 1279-1288. [CrossRef]

85. Buckley, R.; Clough, E.; Warnken, W.; Wild, C. Coliform Bacteria in Streambed Sediments in a Subtropical Rainforest Conservation Reserve. Water Res. 1998, 32, 1852-1856. [CrossRef]

86. Crabill, C.; Donald, R.; Snelling, J.; Foust, R.; Southam, G. The Impact of Sediment Fecal Coliform Reservoirs on Seasonal Waterquality in Oak Creek, Arizona. Water Res. 1999, 33, 2163-2171. [CrossRef]

87. Smith, J.; Edwards, J.; Hilger, H.; Steck, T.R. Sediment Can Be a Reservoir for Coliform Bacteria Released into Streams. J. Gen. Appl. Microbiol. 2008, 54, 173-179. [CrossRef]

88. Jamieson, R.C.; Joy, D.M.; Lee, H.; Kostaschuk, R.; Gordon, R.J. Resuspension of Sediment-Associated Escherichia Coli in a Natural Stream. J. Environ. Qual. 2005, 34, 581-589. [CrossRef]

89. Fries, J.S.; Characklis, G.W.; Noble, R.T. Sediment-Water Exchange of Vibrio Sp. and Fecal Indicator Bacteria: Implications for Persistence and Transport in the Neuse River Estuary, North Carolina, USA. Water Res. 2008, 42, 941-950. [CrossRef] [PubMed]

90. Smith, J.E.; Stocker, M.D.; Hill, R.L.; Pachepsky, Y.A. The Effect of Temperature Oscillations and Sediment Texture on Fecal Indicator Bacteria Survival in Sediments. Water Air Soil Pollut. 2019, 230, 1-11. [CrossRef]

91. Nowicki, S.; DeLaurent, Z.R.; de Villiers, E.P.; Githinji, G.; Charles, K.J. The Utility of Escherichia Coli as a Contamination Indicator for Rural Drinking Water: Evidence from Whole Genome Sequencing. PLoS ONE 2021, 16, e0245910. [CrossRef]

92. Noble, R.T.; Lee, I.M.; Schiff, K.C. Inactivation of Indicator Micro-Organisms from Various Sources of Faecal Contamination in Seawater and Freshwater. J. Appl. Microbiol. 2004, 96, 464-472. [CrossRef] [PubMed]

93. Eisenstark, A. Mutagenic and Lethal Effects of Visible and Near-Ultraviolet Light on Bacterial Cells. Adv. Genet. 1971, 16, 167-198. [CrossRef] [PubMed]

94. Ziegelhoffer, E.C.; Donohue, T.J. Bacterial Responses to Photo-Oxidative Stress. Nat. Rev. Microbiol. 2009, 7, 856-863. [CrossRef] [PubMed]

95. Kay, D.; Stapleton, C.M.; Wyer, M.D.; McDonald, A.T.; Crowther, J.; Paul, N.; Jones, K.; Francis, C.; Watkins, J.; Wilkinson, J.; et al. Decay of Intestinal Enterococci Concentrations in High-Energy Estuarine and Coastal Waters: Towards Real-Time T90 Values for Modelling Faecal Indicators in Recreational Waters. Water Res. 2005, 39, 655-667. [CrossRef]

96. Milliman, J.D. Sediment Discharge to the Ocean from Small Mountainous Rivers: The New Guinea Example. Geo-Marine Lett. 1995, 15, 127-133. [CrossRef]

97. Tavares Carneiro, M.; Bandeira Vianna Cortes, M.; Cesar Wasserman, J. Critical Evaluation of the Factors Affecting Escherichia Coli Environmental Decay for Outfall Plume Models. Rev. Ambient. Água 2018, 13. [CrossRef]

98. Le, H.A.; Gratiot, N.; Santini, W.; Ribolzi, O.; Tran, D.; Meriaux, X.; Deleersnijder, E.; Soares-Frazão, S. Suspended Sediment Properties in the Lower Mekong River, from Fluvial to Estuarine Environments. Estuar. Coast. Shelf Sci. 2020, 233, 106522. [CrossRef]

99. Wang, C.; Zheng, S.-S.; Wang, P.-F.; Hou, J. Interactions between Vegetation, Water Flow and Sediment Transport: A Review. J. Hydrodyn. 2015, 27, 24-37. [CrossRef]

100. Teeter, A.M.; Johnson, B.H.; Berger, C.; Stelling, G.; Scheffner, N.W.; Garcia, M.H.; Parchure, T.M. Hydrodynamic and Sediment Transport Modeling with Emphasis on Shallow-Water, Vegetated Areas (Lakes, Reservoirs, Estuaries and Lagoons). Hydrobiologia 2001, 444, 1-23. [CrossRef] 
101. Morgan, J.A.; Hoet, A.E.; Wittum, T.E.; Monahan, C.M.; Martin, J.F. Reduction of Pathogen Indicator Organisms in Dairy Wastewater Using an Ecological Treatment System. J. Environ. Qual. 2008, 37, 272-279. [CrossRef] [PubMed]

102. Scholz, M. Wetland Systems: Storm Water Management Control; Springer Science \& Business Media: Berlin, Germany, 2010.

103. Sani, A.; Scholz, M.; Bouillon, L. Seasonal Assessment of Experimental Vertical-Flow Constructed Wetlands Treating Domestic Wastewater. Bioresour. Technol. 2013, 147, 585-596. [CrossRef]

104. Paing, J.; Guilbert, A.; Gagnon, V.; Chazarenc, F. Effect of Climate, Wastewater Composition, Loading Rates, System Age and Design on Performances of French Vertical Flow Constructed Wetlands: A Survey Based on 169 Full Scale Systems. Ecol. Eng. 2015, 80, 46-52. [CrossRef]

105. Almuktar, S.A.A.A.N.; Abed, S.N.; Scholz, M. Wetlands for Wastewater Treatment and Subsequent Recycling of Treated Effluent: A Review. Environ. Sci. Pollut. Res. 2018, 25, 23595-23623. [CrossRef]

106. Mthembu, M.; Odinga, C.; Swalaha, F.M.; Bux, F. Constructed Wetlands: A Future Alternative Wastewater Treatment Technology. Afr. J. Biotechnol. 2013, 12, 4542-4553. [CrossRef] 